\title{
ОПЫТ КОМПЛЕКСНОГО ИСПОЛЬЗОВАНИЯ ЗОЛОТОСОДЕРЖАЩЕГО СЫРЬЯ ПРИ ПРОИЗВОДСТВЕ ДРАГОЦЕННЫХ МЕТАЛЛОВ
}

\author{
В.В.ЖМУРОВА, Н.В.НЕМЧИНОВА
}

Иркутский национальный исследовательский технический университет, Иркутск, Россия

\begin{abstract}
С истощением богатых золотосодержащих руд в переработку все чаще стали вовлекаться полиметаллические руды, которые помимо драгоценных металлов содержат другие элементы, представляющие интерес для их извлечения. Проблема использования таких руд решается крайне трудно из-за высокой себестоимости доизвлечения сопутствующих ценных компонентов. В работе приведены результаты исследований по комплексному использованию добываемого золотосодержащего сырья на примере месторождения «Березитовое» (Амурская обл.), характеризующегося низким содержанием драгоценных металлов и наличием в значительном количестве тяжелых цветных металлов (меди, свинца). Были проведены экспериментальные работы по получению меди методом цементации из растворов, образующихся после выщелачивания соляной кислотой примесей золотосодержащих катодных осадков. Металлом-цементатором служила железная стружка (отходы токарного цеха предприятия). Далее было предложено использование цементационной меди в качестве коллектора при переплавке шлаков - отходов переработки бедных полиметаллических руд, содержащих драгоценные металлы. Авторами были получены слитки сплава лигатурного золота с массовой долей золота $16 \%$, отвечающие требованиям ТУ 117-2-7-75 по содержанию цветных металлов. Серебро, частично перешедшее в раствор при солянокислой обработке катодных осадков, также восстанавливается совместно с цементационной медью и при последующей плавке переходит в сплав лигатурного золота. Таким образом, предложенный авторами метод способствует снижению содержания драгоценных металлов в «незавершенном производстве» золотоизвлекательной фабрики. Показана возможность реализации полученной цементационной меди на предприятиях, специализирующихся на изготовлении ювелирных изделий; ожидаемый экономический эффект при этом составил более 1,8 млн руб.
\end{abstract}

Ключевые слова: металлургия; драгоценные металлы; катодные осадки; примеси; цементационная медь; извлечение

Как цитировать эту статью: Жмурова В.В. Опыт комплексного использования золотосодержащего сырья при производстве драгоценных металлов / В.В.Жмурова, Н.В.Немчинова // Записки Горного института. 2018. T. 233. C. 506-511. DOI: 10.31897/PMI.2018.5.506

Введение. Рациональное использование природных ресурсов является одним из приоритетных направлений в сфере недропользования. При разработке золотосодержащих месторождений помимо задач максимально полного извлечения драгоценных металлов и защиты окружающей среды также актуальным является комплексное использование перерабатываемого сырья. В настоящее время данная проблема решается крайне трудно из-за высокой себестоимости добычи сопутствующих ценных элементов и нерентабельности их последующей переработки $[12,13]$. Чаще всего решение данного вопроса ограничивается уплатой штрафов за несоблюдение требований по рациональному использованию недр или пересмотром условий лицензии на добытое минеральное сырье (Закон РФ «О недрах» №2395-1 от 21.02.1992).

На долю перерабатываемых золотосодержащих полиметаллических руд приходится около $10 \%$ от всех руд, содержащих драгоценные металлы, но данное значение неуклонно возрастает в связи с истощением запасов месторождений, богатых по содержанию золота и серебра. К ним относятся руды, имеющие в своем составе драгоценные металлы, два или более промышленных компонента: $\mathrm{Cu}, \mathrm{Pb}, \mathrm{Zn}$ и др. Так, руды с содержанием менее $60 \%$ кварца и не более $12 \%$ оксида алюминия (золото-кварцевые) часто используют в качестве флюсов в пирометаллургических процессах. Промышленную ценность представляют в данном случае и золото, и кварц. При переработке пиритно-арсенопиритных золотосодержащих концентратов возможно получение серной кислоты [14]. При переработке золото-сурьмянистых руд одновременно выделяют богатый сурьмяный концентрат. Промышленное значение также имеют золото-свинцовые, золотоцинковые, золото-теллуровые, золото-висмутовые, золото-вольфрамовые, золото-баритовые, золото-турмалиновые и другие руды.

Основные золотополиметаллические месторождения в России - Гайское (Оренбургская обл.), Березитовое (Амурская обл.), Рубцовское (Алтайский край), Николаевское, Верхнее, Партизанское (Дальний Восток), Дукат, Хатанга (Магаданская обл.), Нежданинское (Якутия) и др.характеризуются наличием других ценных компонентов. 
Постановка задачи. Месторождение «Березитовое» относится к бедным полиметаллическим рудам с содержанием, г/т: золота2,1, серебра - 18,5. Кроме драгоценных металлов, в состав данной руды входят различные минералы со средним содержанием, \% по массе: свинец $-0,5$, цинк - 1,5, медь - 0,03. Для извлечения ценных компонентов специалистами АО «Иргиредмет» (г. Иркутск) была разработана комбинированная технология переработки руды с получением сплава лигатурного золота, свинцового и цинкового концентратов, но из-за высокой стоимости переработки руды в настоящее время ведется добыча только золота и серебра. Технологическая схема переработки руд данного месторождения представлена на рис.1.

По мере промышленной разработки данного месторождения содержание металлов-примесей в руде увеличивается, а содержание драгоценных металлов падает, что заставляет предприятие принимать меры по устранению негативного влияния на химический состав получаемых сплавов золота и серебра металлов-примесей, переходящих в готовую продукцию [16].

Одним из основных сопутствующих металлов в руде является медь, которая по своим химическим свойствам близка к драгоценным металлам и при выщелачивании переходит в раствор, образуя устойчивые цианистые комплексы, которые при накоплении могут препятствовать растворению золота и серебра $[6,10,11]$. В табл.1 приведены данные о химическом составе золотосодержащих цианистых растворов ООО «Березитовый рудник», полученных по технологической схеме (рис.1), атомно-абсорбционного анализа на приборе «Квант-2АТ» (Россия).

Таблица 1

Химический состав золотосодержащих цианистых растворов

\begin{tabular}{c|c|c|c}
\hline \multirow{2}{*}{ Номер опыта } & \multicolumn{3}{|c}{ Содержание элементов, г $/ \mathbf{M}^{3}$} \\
\cline { 2 - 4 } & $\mathrm{Au}$ & $\mathrm{Ag}$ & $\mathrm{Cu}$ \\
\hline \multirow{2}{*}{1} & 24 & 125 & 1081 \\
2 & 36 & 0,1 & 334 \\
3 & 125 & 118 & 780 \\
4 & 80 & 140 & 575 \\
5 & 110 & 13 & 158
\end{tabular}

Из данных табл.1 видно, что содержание меди в растворе в несколько раз превышает содержание драгоценных металлов. На рис.2 представлена карта распределения характеристического рентгеновского излучения образца катодного осадка, полученная при изучении химического состава методом рентгеноспектрального микроанализа, проведенного на микроанализаторе JXA8200 (фирма «Interactive Corporation», Япония).

На карте (рис.2) изменение интенсивности рентгеновского излучения определяемого элемента отражается в цвете от черного до красного. Черному цвету соответствует минимальная интенсивность элемента на данной площади поверхности. Если содержание элемента в области карты меняется от 1 до $100 \%$ - красный цвет будет отвечать области $100 \%$, а синий - $1 \%$; в случае изменения химического состава от 0,1 до 1 \% красным на карте будет область с содер- 


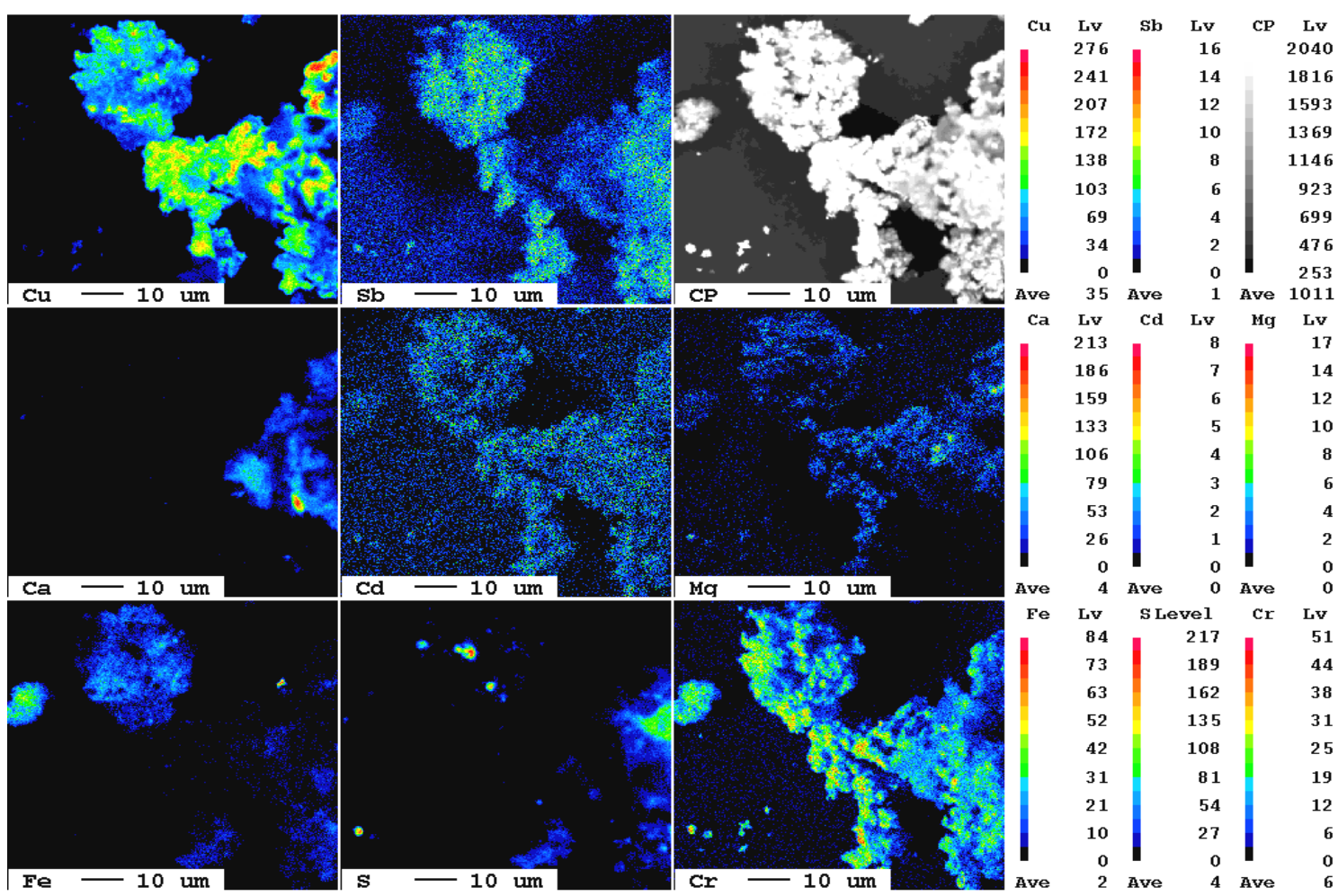

Рис.2. Карта распределения характеристического рентгеновского излучения элементов в образце катодного осадка (для $\mathrm{Cu}, \mathrm{Sb}, \mathrm{Ca}, \mathrm{Cd}, \mathrm{Mg}, \mathrm{Fe}, \mathrm{S}, \mathrm{Cr}$ )

жанием $1 \%$, а черный цвет будет соответствовать нулевому содержанию (режим съемки: СР поверхность в обратно рассеянных электронах). Содержание меди в образце катодного осадка преобладает по сравнению с другими элементами.

Медь, присутствующая в катодных осадках, при последующей их переработке попадает в готовую продукцию - сплав лигатурного золота. В табл.2 представлены данные химического состава сплава лигатурного золота, получаемого на предприятии (массовая доля драгоценных металлов определялась пробирным методом анализа).

Таблица 2

Химический состав сплава лигатурного золота

\begin{tabular}{c|c|c|c|c}
\hline \multirow{2}{*}{ Номер сплава } & \multicolumn{4}{|c}{ Массовая доля, \% } \\
\cline { 2 - 5 } & $\mathrm{Au}$ & $\mathrm{Ag}$ & $\mathrm{Cu}$ & Прочие \\
\hline \multirow{2}{*}{1} & 16 & 17 & 32 & 35 \\
2 & 14 & 13 & 28 & 45 \\
3 & 22 & 32 & 43 & 3 \\
4 & 18 & 28 & 49 & 10 \\
5 & 24 & 27 & 39 & 1 \\
6 & 19 & 18 & 42 & 12 \\
7 & 20 & 27 & 42 & 16 \\
\hline Среднее & 19 & 23 & &
\end{tabular}

Как видно из данных табл. 2, массовая доля меди в сплаве варьируется в диапазоне 28-62 \%, что значительно увеличивает затраты предприятия на последующие аффинажные услуги своей продукции. Наличие большого количества меди и других примесей в сплаве также является причиной недостоверного опробования золота $[5,6]$. В сплавах с повышенным содержанием меди наблюдается весьма неравномерное распределение золота и серебра; последние аккумулируются преимущественно в нижней части слитка $[1,9]$.

Одним из способов удаления меди из сплава является предварительная солянокислая обработка катодных осадков перед плавкой, на что и были направлены наши исследования [7]. Дан- 
ная операция позволила перевести в раствор до 80 \% меди в виде дихлоркупратов щелочных и щелочно-земельных металлов. Растворы после выщелачивания примесей катодных осадков нейтрализовывались и сбрасывались в дренаж.

Для выделения меди из растворов можно использовать процесс цементации железным скрапом. Как известно, данный способ является эффективным и малозатратным [4].

В основе технологии лежит реакция вытеснения меди из раствора более электроотрицательным металлом- железом [8]:

$$
\mathrm{Na}_{2} \mathrm{CuCl}_{4}+\mathrm{Fe}=\mathrm{Cu}+\mathrm{FeCl}_{2}+2 \mathrm{NaCl}, \quad \Delta G_{298}^{0}=-140,61 \text { кДж/моль. }
$$

Расчет величины изменения энергии Гиббса показал, что данная реакция термодинамически возможна.

По результатам проведенных нами экспериментов была предложена технология, позволяющая выделить ионы меди из растворов в виде металла и использовать ее далее в качестве коллектора в процессе получения драгоценных металлов для переплавки шлаков $[1,15]$.

Результаты и обсуждение. Цементация ионов меди из растворов, образующихся после обработки катодных осадков соляной кислотой, производилась с использованием железной стружки - отходов токарного цеха предприятия. Продолжительность цементации составила 1 ч. Затем цементационный осадок отфильтровывался и высушивался в течение 1-2 ч. Результаты анализа химического состава (атомно-абсорбционным методом анализа на приборе «Квант-2АТ» (Россия)) цементационной меди представлены в табл.3.

Химический состав цементационной меди

\begin{tabular}{c|c|c|c|c}
\hline \multirow{2}{*}{ Номер опыта } & \multicolumn{4}{|c}{ Содержание элементов, \% по массе } \\
\cline { 2 - 5 } & $\mathrm{Cu}$ & $\mathrm{Pb}$ & $\mathrm{Ag}$ & Прочие $^{*}$ \\
\hline \multirow{2}{*}{1} & 96,5 & - & 3,5 & - \\
2 & 95,3 & 0,1 & 2,2 & 2,4 \\
3 & 94,8 & 0,5 & 1,9 & 0,2 \\
4 & 97,8 & 0,2 & 1,8 & 1,35 \\
\hline \multirow{2}{*}{ Среднее } & 96,1 & 0,2 & 2,35 & \\
\end{tabular}

* Элементы, содержание которых не учитывалось в экспериментах из-за их незначительного количества.

Из данных табл.3 видно, что выделившаяся цементационная медь содержит небольшое количество примесей; ее химический состав в первую очередь зависит от химического состава исходных катодных осадков. Незначительное количество серебра, перешедшее в раствор при солянокислом выщелачивании, также восстанавливается железом при цементации и переходит в цементационную медь, что является благоприятным условием для предотвращения безвозвратных потерь данного драгоценного металла и увеличения его последующего суммарного извлечения при переработке руды.

Применение цементационной меди в производстве драгоценных металлов. Катодные осадки служат исходным сырьем для производства сплава лигатурного золота пирометаллургическим способом (плавкой) [1]; чем меньшее количество примесей тяжелых цветных металлов в них, тем соответственно более химически чистыми получаются сплавы драгоценных металлов.

Наиболее негативное влияние на процесс плавки катодных осадков по традиционной технологии оказывают $\mathrm{Cu}, \mathrm{Pb}$ и $\mathrm{S}$, так как медь и свинец являются коллекторами драгоценных металлов при плавке: аккумулируют золото и серебро [3]. Присутствие серы в катодных осадках является причиной образования промежуточной штейновой фазы при плавке, в которой содержится большое количество золота в виде корольков. При плавке катодных осадков также образуются богатые по содержанию драгоценных металлов шлаки. Все отходы плавки, содержащие драгоценные металлы (шлак, штейн, бой тиглей и другие промпродукты), возвращаются в «голову» процесса (в цикл измельчения руды). Различные попытки переплавки шлака и штейна с целью 
доизвлечения $\mathrm{Au}$ и $\mathrm{Ag}$ не давали положительных результатов. В связи с этим, а также с необходимостью максимального извлечения драгоценных металлов, нами были проведены экспериментальные работы по переплавке шлаков [1] с использованием в качестве медного коллектора меди, полученной цементацией из солянокислых растворов выщелачивания.

Для проведения экспериментальных плавок были взяты две партии шлака, содержащие штейновую фазу общей массой 20 кг. На это количество были взяты для плавки флюсы, \%: бура - 50, сода - 10, цементационная медь - 2-5.

В нагретую индукционную печь засыпали буру; после ее расплавления оставшаяся часть флюсов смешивалась со шлаком и добавлялась в плавку. Затем после расплавления всего шлака добавлялась цементационная медь и плавилась до получения равномерного по составу расплава. В результате плавки было получено два слитка сплава лигатурного золота с массовой долей соответственно, \%: $\mathrm{Au}-16,1, \mathrm{Ag}-21,5$. Выход слитков составил 17,84 и 11,20\%.

Таким образом, в результате плавки шлаков на медный коллектор были получены слитки лигатурного золота, соответствующие ТУ117-2-7-75, для отправки на последующий аффинаж. Данная технология применения цементационной меди в качестве коллектора драгоценных металлов при плавке шлаков была рекомендована для использования на действующем производстве.

Полученная цементационная медь также может быть реализована на медеплавильные заводы или предприятия, специализирующиеся на производстве ювелирных изделий.

Экономический эффект от реализации цементационной меди. Содержание меди в цементном осадке составляет $\approx 96 \%$, что позволяет при выделении ее из раствора реализовывать на медеперерабатывающие предприятия. Расчет ожидаемого экономического эффекта от реализации данной цементационной меди на примере ОАО «Красноярский завод цветных металлов им. В.Н.Гулидова», где возможно ее применение для производства ювелирных изделий, показал возможность получения экономического эффекта 1883700 руб./год (в расчете использовались данные по количеству образующейся при цементации меди $(2,691$ т/год) и стоимости приема металла на заводе 700 руб./кг). При расчете не учитывались транспортные расходы на доставку меди, так как данный вид промпродукта можно транспортировать совместно со сплавом лигатурного золота, направляемого на аффинажный завод, расположенный также в г. Красноярске, и капитальные затраты на используемое оборудование (все необходимое оборудование - контактный чан, сушильная печь, вакуум-фильтр и др. - уже имеется на предприятии).

Таким образом, предприятие может получить прибыль (без значительных дополнительных затрат) от реализации цементационной меди.

Заключение. Проведенные исследования показали целесообразность использования технологии цементации меди из солянокислых растворов, полученных при выщелачивании примесей катодных осадков. Массовая доля меди в полученном цементационном осадке составила более $95 \%$. Серебро, перешедшее в раствор при солянокислой обработке катодных осадков, при цементации восстанавливается совместно с медью и при последующем использовании ее в качестве коллектора для переплавки шлаков переходит в сплав лигатурного золота. Предложенные мероприятия способствуют снижению содержания драгоценных металлов «в незавершенном производстве» золотоизвлекательной фабрики. Предприятие может также получить дополнительную прибыль в размере более 1,8 млн руб. в год от реализации цементационной меди на медеперерабатывающие предприятия. Таким образом, предлагаемая авторами технология способствует комплексному использованию природного рудного сырья.

\section{ЛИТЕРАТУРА}

1. Баликов С.В. Плавка золотосодержащих концентратов / С.В.Баликов, В.Е.Дементьев. Иркутск: Иргиредмет, 2002.323 с.

2. Барченков B.B. Технология гидрометаллургической переработки золотосодержащих флотоконцентратов с применением активных углей. Чита: Поиск, 2004. 242 с.

3. Ванюков А.В. Теория пирометаллургических процессов / А.В.Ванюков, В.Я.Зайцев. М.: Металлургия, 1993. 384 с.

4. Вольдман Г.М. Теория гидрометаллургических процессов / Г.М.Вольдман, А.Н. Зеликман. М.: Интермет Инжиниринг, 2003. $464 \mathrm{c}$.

5. Жмурова В.В. Разработка способа получения сплава благородных металлов с минимальным количеством примесей// Цветные металлы - 2010: Материалы II Междунар. конгресса. Красноярск: Изд-во ООО «Версо», 2010. С. $325-332$.

6. Жмурова В.В. Исследование по повышению качества катодных осадков, получаемых при переработке золотосодержащего полиметаллического сырья / В.В.Жмурова, А.И.Карпухин // Цветные металлы. 2012. № 9. С. 37-40. 
Опыт комплексного использования золотосодержащего сырья...

7. Жмурова В.В. Кислотное выщелачивание примесей золотосодержащего катодного осадка / В.В.Жмурова, Н.В.Немчинова, Г.Г.Минеев // Цветные металлы. 2017. № 7. С 41-46.

8. Морачевский А.Г. Термодинамические расчеты в металлургии. М.: Металлургия, 1993. 303 с.

9. Патент 2598726 РФ. Способ комплексной переработки материала, содержащего драгоценные металлы / С.М.Совка, И.А.Малыхин, О.В.Телипенко. Опубл. 27.09.2016. Бюл. № 27.

10. Agorhom E.A. Influence of gold mineralogy on its flotation recovery in a porphyry copper-gold ore / E.A.Agorhom, W.Skinner, M.Zanin // Chemical Engineering Science. 2013. Vol. 99. № 9. P. 127-138.

11. Canda L. Methods for recovering precious metals from industrial waste / L.Canda, T.Heput, E.Ardelean // IOP Conference Series: Materials Science and Engineering. 2016. Vol. 106. № 1. P. 12-20.

12. Hussin A.M. Statistical optimization of gold recovery from difficult leachable sulphide minerals using bacteria/ A.M.Hussin, Ahmed. Ayman A.El-Midany // Materials Testing. 2012. Vol. 54. № 5. P. 351-357.

13. Kyle J.H. Review of trace toxic elements $(\mathrm{Pb}, \mathrm{Cd}, \mathrm{Hg}, \mathrm{As}, \mathrm{Sb}, \mathrm{Bi}, \mathrm{Se}, \mathrm{Te})$ and their deportment in gold processing. Part II: Deportment in gold ore processing by cyanidation / J.H. Kyle, P.L. Breuer, K.G. Bunney, R. Pleysier // Hydrometallurgy. 2012. Vol. 111-112. P. 10-21.

14. Mohammadnejad S. The effect of grinding on the preg-robbing of gold quartz / S.Mohammadnejad, J.L.Provis, S.J.Van Deventez // International Journal of Mineral Processing. 2014. Vol. 128. P. 1-5.

15. Syed S. Recovery of gold from secondary sources - A review // Hydrometallurgy. 2012. Vol. 115-116. P. 30-51.

16. Tremolada $J$. The preg-robbing of gold and silver by clays during cyanidation under agitation and heap leaching conditions / J.Tremolada, R.Dzioba, A.Bernardo-Sanchez, J.M.Menendez-Agnado // International Journal of Mineral Processing. 2010. Vol. 94. P. 67-71.

Авторы: В.В. Жмурова, cm. преподаватель, v_pichugina@list.ru (Иркутский национальный исследовательский технический университет, Иркутск, Россия), Н.В. Немчинова, д-р техн. наук, профессор, пinavn@yandex.ru (Иркутский наичиональный исследовательский технический университет, Иркутск, Россия).

Статья поступила в редакиию 10.05.2018.

Статья принята к публикации 27.06.2018. 